\title{
Isolation and characterization of endothelial progenitor cells from Rhesus monkeys
}

\author{
Wen Sun, Lily Zheng, Pengfei Han and Y James Kang ${ }^{*}$
}

\begin{abstract}
Background: Endothelial progenitor cells (EPCS) are increasingly becoming a major focus of regenerative medicine research and practice. The present study was undertaken to establish an appropriate procedure for isolation and characterization of EPCS from Rhesus monkeys for regenerative medicine research.

Result: Selective CD34+ and nonselective mononuclear EPCS were isolated from bone marrow and cultured under varying conditions. The results showed that nonselective mononuclear EPCs were a better choice for high yield of the target cells. The cells grew in M 200 better than in EGM-2, and supplementation with fetal bovine serum promoted cell proliferation; but serum level at $7.5 \%$ was better than at $10 \%$. In addition, surface coating of the culture dishes with human fibronectin significantly improved the proliferation and ontogeny of the isolated EPCs. Immunocytochemistry including detection of markers CD34, CD133 and CD31 and double-staining for Ac-LDL and lectin verified the purity of the cultured mononuclear EPCs.
\end{abstract}

Conclusion: By a thorough analysis, we established a practical procedure for isolation and propagation of EPCS from Rhesus monkeys. This procedure would help using these valuable cells for regenerative medicine research.

Keywords: EPCs, Isolation, Cell culture, Cell proliferation, Characterization, Monkey

\section{Background}

Endothelial progenitor cells (EPCs) are increasingly becoming a major focus of regenerative medicine research and practice. These cells are enriched in the mononuclear cell fraction of peripheral blood but have also been isolated from bone marrow, the vessel wall, and a number of other organs and tissues [1-3]. Both experimental [4-7] and human clinical trials of EPC-based therapies [8-10] have generated encouraging results that underscored the significance of this cell type in cardiovascular medicine; a role for EPCs in the modulation of angiogenesis has been recognized [1-3]. However, there are a number of elusive issues in a comprehensive understanding of the usefulness of EPCs. For instance, it is unknown for the precise ontogeny and lineage of these cells, the true extent to which EPCs participate in neovascularization and vascular repair, and the efficacy of EPC-based regenerative therapies [11-13].

The encouraging data for the clinically potential of EPCs and the challenges for their development for

\footnotetext{
* Correspondence: jameskang01@yahoo.com

Regenerative Medicine Research Center, West China Hospital, Sichuan University, Chengdu, Sichuan 610041, China
}

clinical use have prompted an explosion of interest in experimental and clinical understanding of EPCs. Studies have focused on the role of EPCs in postnatal vasculogenesis in human health and disease [14-18]. In this context, purification and characterization of EPCs from rodent animal models have generated exciting data [16,19-21]. However, there are significant limitations in these rodent studies, and the most noticeable restriction is the uncertainty of the extrapolation of the experimental data to humans due to remarkable variations in many aspects of physiology and pathogenesis between rodents and humans [22].

Non-human primate models of human disease and pathogenesis have become increasingly demanded experimental models for cardiovascular medicine. This is due largely to the emphasis of translational medicine research and the close similarity between non-human primates and humans in many aspects of cardiovascular physiology and pathology [23,24]. With regard to the study of EPCs in cardiovascular medicine, the monkey model would provide an excellent assessment for the development of their potential for clinical application. It is thus of significant experimental and clinical interest to develop a procedure 
for the purification and characterization of EPCs isolated from monkeys for the purpose stated above.

In the present study, we carefully analyzed the effects of different procedures including purification, culturing conditions, culture medium compositions, and selection of culture glassware on EPCs isolated from Rhesus monkeys. An optimized procedure was developed to achieve a high yield and stable culture of the EPCs from monkeys. This procedure would greatly enhance the efficacy and reliability of the cultured EPCs isolated from monkeys for the studies of their growth and differentiation, as well as their lineage and participation in neovascularization.

\section{Results}

\section{Effects of isolation procedures on the yield and} characterization of EPCs isolated from Rhesus monkeys

Mononuclear EPCs isolated from bone marrow by gradient centrifugation were either directly cultured or subjected to CD34-affinity column for further purification. The data presented in Figure 1A show the difference in the morphology of the EPCs in cultures. Adherent CD34+ mononuclear cells grew into cerioid colonies after 5-7 days; cobblestone-appearance colonies were observed after 9-11 days; and spindle shaped colonies existed all the time. On the 4th day after the first passage, which was conducted approximately 2 weeks after the palting, cells grew more uniformly with the increased spindle shaped cells and losing of stereognosis.

Adherent unselected mononuclear EPCs grew into cerioid colonies after 4-6 days, and spindle shaped and cobblestone-appearance colonies were both observed during further culturing. The first passage was conducted 8-10 days after the plating and cell morphology changed with the increased spindle shaped cells and losing of stereognosis observed on the $1^{\text {st }}$ day after $1^{\text {st }}$ passage.

Comparing these two isolation methods, selecting CD34+ mononuclear cells required more time, but the yield of CD34+ mononuclear cells was lower than unselected cells, and the CD34+ cells grew much slower.
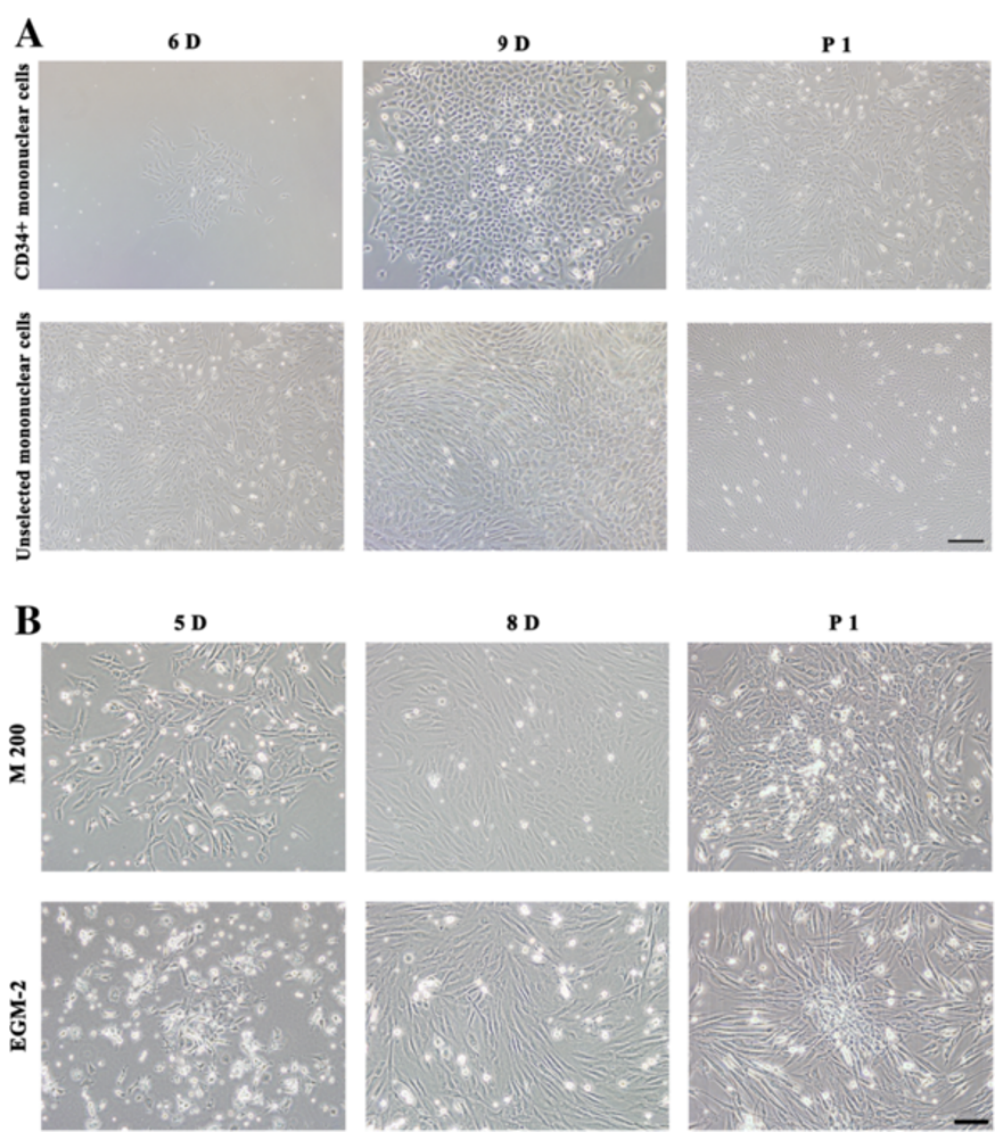

Figure 1 The morphology of EPCs isolated from Rhesus monkeys. A. Selected CD34+ mononuclear cells and unselected mononuclear cells were cultured in M 200, observed on day 6 (6D) or day 9 (9D) after culturing and day 4 after the first passage (P1). Both selected CD34+ and unselected mononuclear cells were cerioid shape on day 6 , formed cobblestone-appearance colonies on day 9, and become more spindle shape with the loss of stereognosis after first passage. Bar $=200 \mu \mathrm{m}$. B. Unselected mononuclear cells were cultured in either M 200 or EGM-2 media, observed on day 5 (5D), day 8 (8D) after culturing and day 1 after the first passage (P1). Cells cultured in M 200 proliferated faster than in EGM-2, but cells in EGM-2 had better stereognosis. Bar $=100 \mu \mathrm{m}$. 
Therefore, unselected mononuclear EPCs were chosen to perform the following experiments.

\section{Effects of culture media on EPCs}

The unselected mononuclear EPCs were equally divided and cultured in two different media: M 200 and EGM-2. Figure $1 \mathrm{~B}$ shows the difference in morphology of the EPCs under two conditions. Both spindle shaped and cobblestone-appearance cells were observed in M 200 and EGM-2. Cells cultured in M 200 proliferated faster than in EGM-2, but cells had better stereognosis in EGM-2.

\section{Effects of serum concentrations on EPCs}

The unselected mononuclear EPCs were cultured in media supplemented with varying concentrations of FBS, as shown in Figure 2. On the third day, cells in the media supplemented with FBS grew faster than in media without FBS supplementation, and this phenomenon was more obvious on the 6th day and last until the 9th day. However, cells cultured in media containing 7.5\% FBS proliferated better than in media supplemented with 10\% FBS.

\section{Effects of culture dishes surface coating on EPCs}

The unselected mononuclear EPCs were plated on culture dishes without coating or coated with $25 \mu \mathrm{g} / \mathrm{ml} \mathrm{FN}$, as shown in Figure 3. On the 5th day, cells seeded on FNcoated dishes adhered much better than cells cultured in dishes without coating, which remained observable until on the 8th day. Comparing the effects between FBS supplementation and FN coating, we found that the effect of FN coating was similar with FBS supplementation, but FBS jeopardizes the multipotential of stem cells [25].

\section{Characterization of cells in cultures}

Unselected mononuclear EPCs were cultured on human FN coated culture dishes and in M 200 or EGM-2 without FBS supplementation. Under this condition, cells were characterized by surface markers CD34, CD133, CD31, by FITC-lectin staining, and by the uptake of Dil AcLDL. FITC-lectin staining and Dil AcLDL uptake are classical methods for EPCs characterization; binding of lectin is specific for human endothelial cells, and uptake of Dil AcLDL is a function associated with endothelial cells $[3,26,27]$. There were no differences in the expression of CD34, CD133, and CD31 between the two different media (data not shown). The data presented in Figure 4 show that almost all the cells were bound with FITC-lectin, but uptake of Dil AcLDL was only observed in a portion of cell population. Importantly, there was much more double-positive staining of FITC-lectin and Dil AcLDL in cells cultured in EGM-2 than those in M 200.

\section{Discussion}

There are several reports on isolation and culturing of EPCs from rodent models $[16,28]$. However, this is the first report to describe a procedure to isolate and culture EPCs from Rhesus monkeys. There were no special requirements for
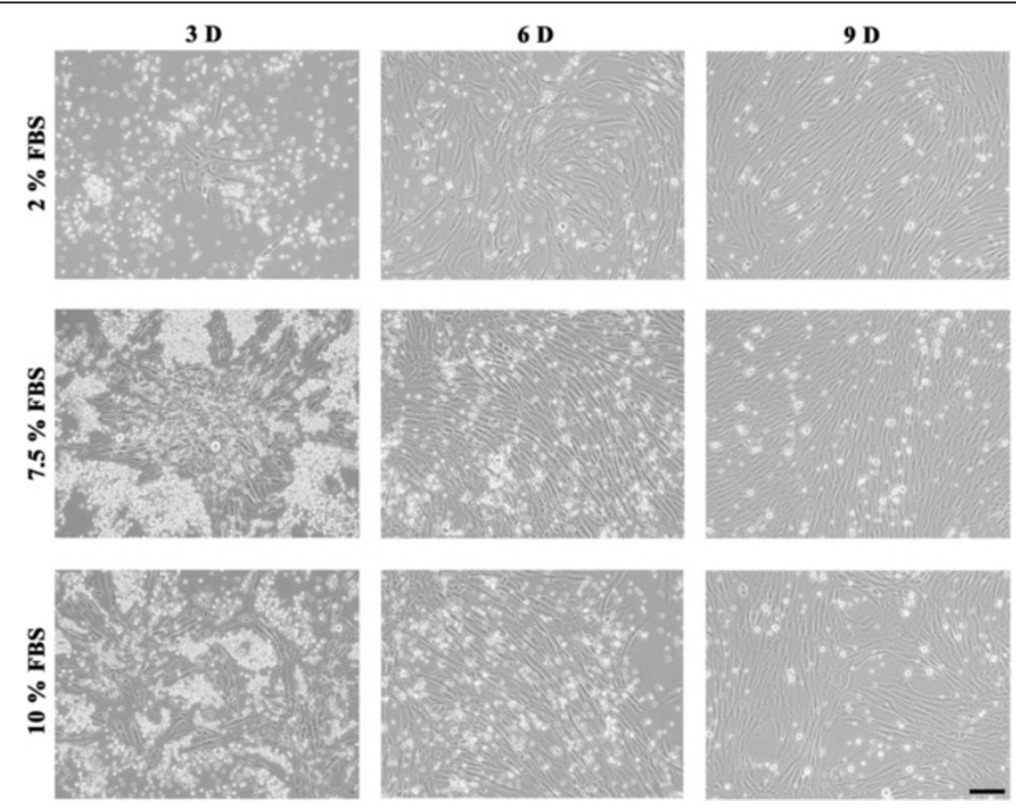

Figure 2 Effects of serum concentrations on EPCs in cultures. Unselected mononuclear cells were cultured in M 200 or M 200 supplemented with $7.5 \%$ or $10 \%$ FBS, observed on day 3, day 6 and day 9. Cells in the medium supplemented with FBS grew faster than in medium without FBS supplementation, but cells in the medium supplemented with 7.5\% FBS proliferated better than in the medium supplemented with $10 \% \mathrm{FBS}$. Bar $=100 \mu \mathrm{m}$. 

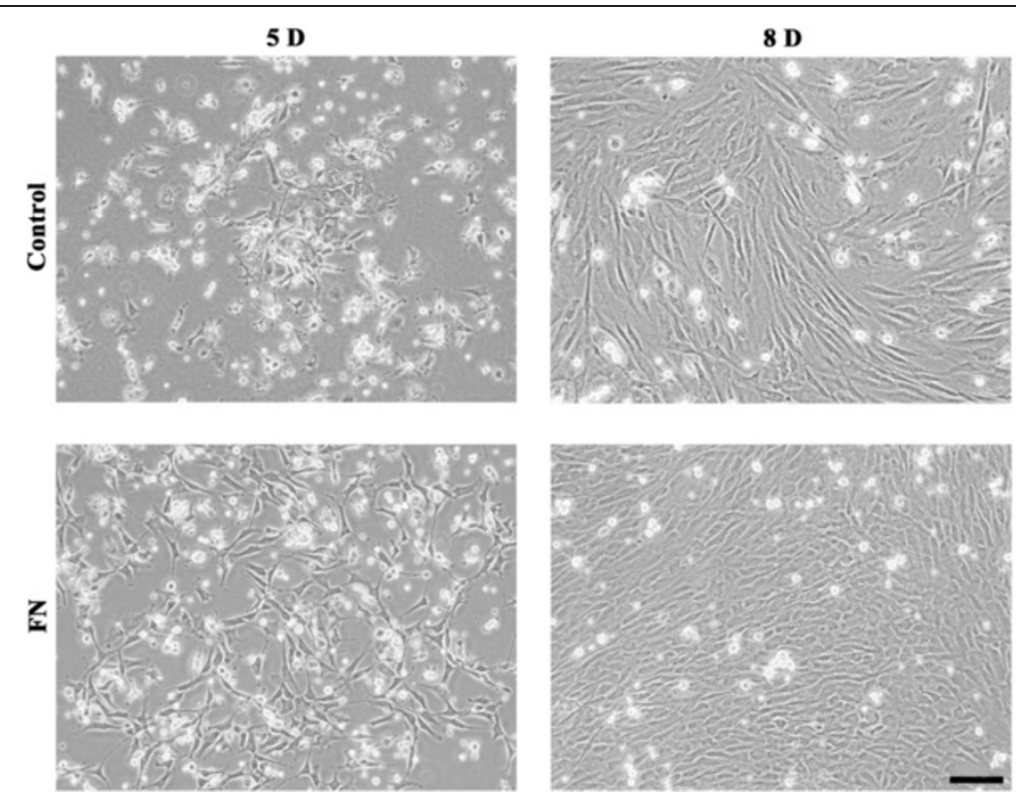

Figure 3 Effects of culture dish surface coating on EPCs in cultures. Unselected mononuclear cells were seeded in EGM-2 medium without serum supplementation on FN coated culture dishes. Morphology of EPCs was respectively observed on day 5 and day 8 after culturing. In the control group, cells were seeded on culture dishes without coating. Cells seeded on FN coated dishes had better adherence than cells seeded on dishes without coating 5 days after culturing, which remained observable until 8 days after culturing. Bar $=100 \mu \mathrm{m}$.

the procedure, but there were specific details to which attention needed to be paid. Separation of CD34+ mononuclear cells would be considered an ideal procedure to purify EPCs, but the low yield in addition to time-consuming would make it less practical for a large scale collection of these cells. Selection of different types of media made a remarkable difference in the maintenance of morphology of the isolated EPC. It was also found that serum supplementation was required, but high concentrations of sera resulted in more differentiation of EPCs in cultures. Finally, a better result was obtained if the culture dishes were coated with FN relative to uncoated culture ware.

There were reports on isolating EPCs using selected $\mathrm{CD} 34+$ or unselected procedures. It appears that the procedure using selected CD34+ mononuclear cells would generate relatively purified EPCs. However, studies have also shown that there was no remarkable advance using the selected CD34+ cells over the unselected mononuclear cells in cultures $[26,27,29]$. In the present study, both procedures were conducted to make a close comparison. The results obtained show that there were no apparent differences in morphology of EPCs in cultures, but there were significant differences in time-consuming and yield between the two procedures. The lower yield of CD34+ mononuclear cells might not reflect an insufficient number of CD34+ cells in the population, but rather resulted from less efficient procedure to separate CD34+ cells using the CD34+ MicroBeads. Considering all of these drawbacks in the current procedure separating CD34+ cells, we recommend that directly using unselected mononuclear cells for the study of EPCs isolated from monkey models.

The differences between M 200 and EGM-2 media include compositions and quantity of the same composition. Although remarkable differences in cell morphology in cultures were not observed between cells cultured in the two differenct media, cells cultured in M 200 proliferated faster than in EGM-2, and cells had better stereognosis in EGM-2. These alterations would suggest that a selection of media for culturing EPCs should consider the need for the eventual application. However, the EGM-2 would a better medium to maintain undifferentiated shape for a longer time of culturing.

It is well known that serum is essential for cell growth and high levels of sera stimulate cell proliferation. It is difficult to define the optimal concentrations of sera in cultures for maintaining undifferentiated morphology of EPCs in cultures but sufficiently supporting cell growth. In this study, we found that serum concentrations at $7.5 \%$ in media would be a better supplementation, and at $10 \%$ promoted differentiation. Therefore, this would provide a reference in the study of EPCs isolated from monkeys.

FN coated culture dishes provide better adherent support for cells in cultures. In the present study, it appeared that FN coating not only provided an adherent support for EPCs, but also helped cells maintain undifferentiated morphorlogy and promote proliferation. The cell growth promotion observed in the FN coated dishes was comparable with that observed in the cultures supplemented with 

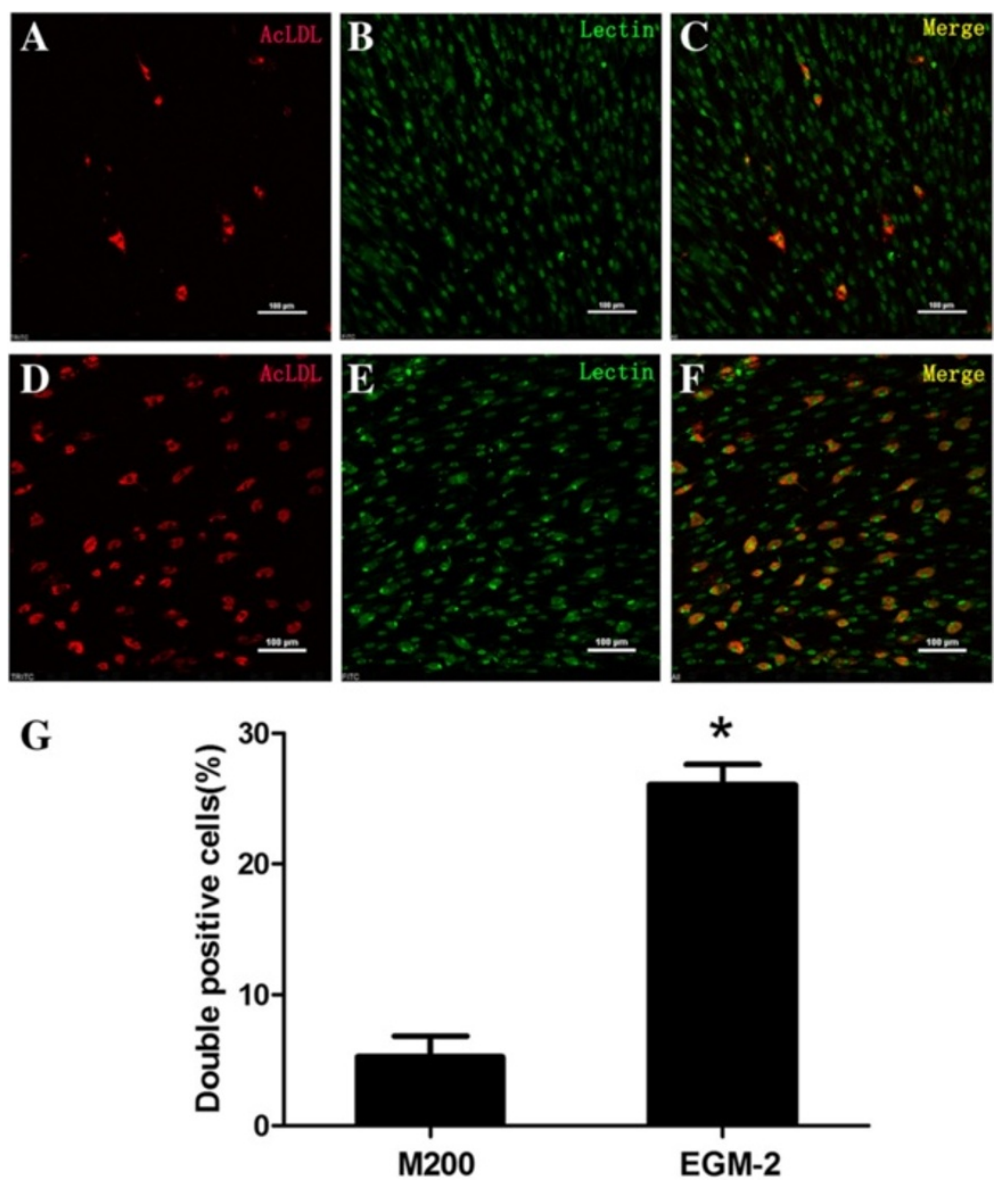

Figure 4 Characterization of cells in cultures by staining cells with FITC-lectin and examing uptake of Dil AcLDL. Unselected mononuclear EPCs were cultured on FN coated dishes and in M 200 or EGM-2 medium, and characterization was proceeded by uptake of Dil AcLDL (left, red) and FITC-lectin staining (middle, green). Double positive cells (right, merge) were observed in both M 200 (A-C) and EGM-2 (D-F) on the $19^{\text {th }}$ day after plating, but the number of double positive cells in EGM-2 was much more than in M 200 (G). ${ }^{*}$, significantly different (P < 0.05). Bar $=100 \mu \mathrm{m}$.

7.5\% FBS. This procedure is thus strongly recommended for culturing EPCs isolated from monkeys.

\section{Conclusions}

Above all, an optimized procedure was developed: unselected mononuclear cells were cultured on human FN coating culture dishes and in EGM-2 without additional FBS supplementation. Under this condition, spindle shaped and cobblestone-appearance cells displayed a better adherence and growth, and were identified to be EPCs.

\section{Methods}

\section{Animals}

Male Rhesus (Macaca mulatta) monkeys, aged 2-3 years old and weighed 4.5 to $6.0 \mathrm{~kg}$, were obtained from Chengdu Ping-An experimental animal breeding and research center, a Chinese government accredited non-human primate center in Sichuan province. The animals were housed in individual cages and acclimatized to the laboratory condition for a period of at least one month. They received conventional laboratory diet with free access to drinking water, which was approved by the Laboratory Animal Management Committee of Sichuan province. All animal procedures were approved by the Institutional Animal Care and Use Committee at the Sichuan University West China Hospital, following the guideline of the US National Institutes of Health.

\section{Isolation of mononuclear cells}

Prior to experimental procedure, all subjects received an intramuscular injection of $5 \mathrm{mg} / \mathrm{kg}$ ketamine and $0.2 \mathrm{mg} / \mathrm{kg}$ midazolam to induce sedation. The hairs covering the iliums or knees at the puncturing sites were shaved and the exposed skin was sterilized by iodophor and alcohol in sequence. Bone marrow puncture was made by using puncture needles and approximately 4-6 $\mathrm{ml}$ bone marrow was aspirated from one or both iliums (or femurs) under strict sterile condition. 
The aspirate was diluted with 4-5 ml L-DMEM media (Gibco, USA), mixed carefully and added on the top of 5-6 ml lymphocyte separation media (density $1.077 \mathrm{~g} / \mathrm{ml}$, TBD, China) at room temperature. After gradient centrifugation at $600 \times \mathrm{g}$ for $20 \mathrm{~min}$, the yellow-white plate (mononuclear cells) was collected, washed and cultivated in media directly or further undergone separation of CD34+ cells.

\section{Separation of CD34+ cells}

CD34+ cells were separated using human CD34 MicroBead Kit (Miltenyi Biotec, Germany) following the instruction provided. In brief, mononuclear cell suspension was centrifuged at $300 \times \mathrm{g}$ for $10 \mathrm{~min}$. The cell pellet was resuspended in $300 \mu \mathrm{L}$ of autoMACS ${ }^{\mathrm{Ta}}$ running buffer (Miltenyi Biotec, Germany), $100 \mu \mathrm{L}$ of FcR blocking reagent, and $100 \mu \mathrm{L}$ of CD34 MicroBeads. After incubation for $30 \mathrm{~min}$ in the refrigerator $\left(2-4^{\circ} \mathrm{C}\right)$, the cells attached to the CD34 MicroBeads were washed with $5-10 \mathrm{~mL}$ of autoMACS ${ }^{\text {m }}$ running buffer followed by centrifugation at $300 \times \mathrm{g}$ for 10 min. The cell pellet was resuspended in $500 \mu \mathrm{L}$ of auto$\mathrm{MACS}^{\mathrm{TM}}$ running buffer, and applied onto an autoMACS running buffer rinsed column on a magnetic separator. The colume was washed 3 times and removed from the separator. The cells were flushed out from the colume using 1.0 $\mathrm{mL}$ of autoMACS ${ }^{\mathrm{TM}}$ running buffer. The collected cells were washed and cultivated.

\section{Cell culture}

Selected CD34+ and unselected mononuclear cells were cultured in media supplemented with low serum growth supplement (LSGS, Gibco, USA) containing fetal bovine serum (FBS), hydrocortisone, human epidermal growth factor (hEGF), basic fibroblast growth factor (bFGF), heparin, and antibiotics (penicillin and streptomycin, Thermo, USA).

\section{Effects of culture media}

Cells were equally divided and cultured in two different media. One portion was cultured in Medium 200 (M 200) supplemented with low serum growth supplement. Another portion was cultured in EGM-2 medium, which is the endothelial cell basal medium-2 plus EGM-2 MV SigleQuots (Lonza, USA), a supplement kit containing FBS, hydrocortisone, hFGF-B, VEGF, R3-IGF-1, ascorbic acid, hEGF, GA-1000, and antibiotics (penicillin and streptomycin, Thermo, USA).

\section{Effects of serum concentrations}

Media were supplemented with FBS at different concentrations: medium with its own serum (serum concentration in M 200 was 2\%, and in EGM-2 was 5\%), and media with added FBS to the final concentration of $7.5 \%$ or $10 \%$ in the medium.

\section{Effects of culture dish surface coating}

Cells were plated on uncoated culture dishes (BD, USA) or human fibronectin (FN, Prospec, Israel) coated culture dishes. The coating was done as follow: $1 \mathrm{ml}$ of $25 \mu \mathrm{g} / \mathrm{ml}$ human FN was added to the dishes and incubated at room temperature for $2 \mathrm{hrs}$, after which the supernatant was removed and dishes were rinsed with PBS buffer.

The first change of media was conducted 3-5 days after the plating. Afterwards, the media were changed every 3 days, with which non-adherent cells were washed away. Cells were digested and passaged at $80 \%-90 \%$ confluence for continuously culturing or characterization.

\section{Characterization of EPCs}

The surface marker CD34 (Abcam, UK), CD133 (HuaAn, China) and CD31 (Abcam, UK) were detected by immuncytochemistry. In addition, cells were stained with FITClabeled lectin (FITC-lectin, Sigma-Aldrich, USA). The uptake of Dil-conjugated acetylated low-density lipoprotein (Dil AcLDL, Invitrogen, USA) was also measured at the same time to define functional EPCs.

\section{Immunocytochemistry}

Cells were digested and seeded on sterile slides, which were put in 6-well plates. Before the detection, media were aspirated and PBS was added to wash cells three times, 5 min each wash. After fixed in cold 4\% paraformaldehyde for 10-15 min and washed with PBS, primary antibodies diluted with PBS containing 10\% serum was added and incubated for $2 \mathrm{hrs}$ at $37^{\circ} \mathrm{C}$ followed by overnight at $4^{\circ} \mathrm{C}$. The secondary antibody diluted with $10 \%$ serum in PBS was incubated for $1.5 \mathrm{hrs}$ at $37^{\circ} \mathrm{C}$. Then DAPI was incubated for 5-10 $\mathrm{min}$ at room temperature and slides were sealed after wash with PBS and examined with laser scanning confocal microscope (LSCM).

\section{FITC-lectin staining and uptake of Dil ACLDL}

Cells were seeded on 24-well plates, and undergone starvation for 24-48 hrs in media without serum, incubated with $200 \mu \mathrm{L} 2.4 \mu \mathrm{g} / \mathrm{ml}$ Dil AcLDL $4 \mathrm{hrs}$ at $37^{\circ} \mathrm{C}$ after medium removal and wash, and fixed in cold $4 \%$ paraformaldehyde for 10-15 min, followed by incubation in $200 \mu \mathrm{L} 10 \mu \mathrm{g} / \mathrm{ml}$ FITC-lectin for $2 \mathrm{hrs}$ at $37^{\circ} \mathrm{C}$, and examined with LSCM after PBS washing.

\section{Statistical analysis}

Data were obtained from three separate experiments and expressed as means \pm S.E.M. The significance of difference between groups was determined by Student T-test. The level of significance was considered when $\mathrm{P}<0.05$.

\section{Competing interests}

The authors declare that they have no competing interests. 


\section{Authors' contributions}

YJK: conceived and designed the study, and wrote the manuscript; WS and $\mathrm{LZ}$ : performed the experiments and data analysis, participated in manuscrip preparation; $\mathrm{PH}$ : participated in animal model preparation and experiments. All authors read and approved the final version of the manuscript.

\section{Acknowledgments}

This study was supported in part by the National Science Foundation of China (NSFC grant 81230004 to YJK) and the Sichuan University West China Hospital. The authors thank Ms. Ling Bai and Jingyao Zhang for technical assistance.

Received: 5 August 2013 Accepted: 12 November 2013

Published: 3 March 2014

\section{References}

1. Martinez-Estrada OM, Munoz-Santos Y, Julve J, Reina M, Vilaro S: Human adipose tissue as a source of Flk-1+ cells: new method of differentiation and expansion. Cardiovasc res 2005, 65:328-333.

2. Peichev M, Naiyer AJ, Pereira D, Zhu Z, Lane WJ, Williams M, Oz MC, Hicklin DJ, Witte L, Moore MA, Rafii S: Expression of VEGFR-2 and AC133 by circulating human $\mathrm{CD} 34(+)$ cells identifies a population of functional endothelial precursors. Blood 2000, 95:952-958.

3. Eggermann J, Kliche S, Jarmy G, Hoffmann K, Mayr-Beyrle U, Debatin KM, Waltenberger J, Beltinger C: Endothelial progenitor cell culture and differentiation in vitro: a methodological comparison using human umbilical cord blood. Cardiovasc Res 2003, 58:478-486.

4. Li HQ, Zhao Q, Zhu D, Liu J, Ye XF: Transplantation of bone marrowderived endothelial progenitor cells preconditioned with ex vivo 17betaestradiol enhances healing efficacy after acute myocardial infarction. Zhonghua xin xue guan bing za zhi 2011, 39:420-423.

5. Yoon CH, Hur J, Park KW, Kim JH, Lee CS, Oh IY, Kim TY, Cho HJ, Kang HJ, Chae $\mathrm{H}$, Yang HK, Oh BH, Park YB, Kim HS: Synergistic neovascularization by mixed transplantation of early endothelial progenitor cells and late outgrowth endothelial cells: the role of angiogenic cytokines and matrix metalloproteinases. Circulation 2005, 112:1618-1627.

6. Kawamoto A, Tkebuchava T, Yamaguchi J, Nishimura H, Yoon YS, Milliken C, Uchida S, Masuo O, Iwaguro H, Ma H, Hanley A, Silver M, Kearney M, Losordo DW, Isner JM, Asahara T: Intramyocardial transplantation of autologous endothelial progenitor cells for therapeutic neovascularization of myocardial ischemia. Circulation 2003, 107:461-468.

7. Badorff C, Brandes RP, Popp R, Rupp S, Urbich C, Aicher A, Fleming I, Busse R, Zeiher AM, Dimmeler S: Transdifferentiation of blood-derived human adult endothelial progenitor cells into functionally active cardiomyocytes. Circulation 2003, 107:1024-1032.

8. Hill JM, Zalos G, Halcox JP, Schenke WH, Waclawiw MA, Quyyumi AA, Finkel T: Circulating endothelial progenitor cells, vascular function, and cardiovascular risk. New Engl j med 2003, 348:593-600.

9. Aoki J, Serruys PW, van Beusekom H, Ong AT, McFadden EP, Sianos G, van der Giessen WJ, Regar E, de Feyter PJ, Davis HR, Rowland S, Kutryk MJ: Endothelial progenitor cell capture by stents coated with antibody against CD34: the HEALING-FIM (Healthy Endothelial Accelerated Lining Inhibits Neointimal Growth-First In Man) Registry. J Am Coll Cardio/ 2005, 45:1574-1579.

10. Kalka C, Masuda H, Takahashi T, Kalka-Moll WM, Silver M, Kearney M, Li T, Isner JM, Asahara T: Transplantation of ex vivo expanded endothelial progenitor cells for therapeutic neovascularization. Proc Natl Acad Sci USA 2000, 97:3422-3427.

11. Hur J, Yoon CH, Kim HS, Choi JH, Kang HJ, Hwang KK, Oh BH, Lee MM, Park YB: Characterization of two types of endothelial progenitor cells and their different contributions to neovasculogenesis. Arterioscler Thromb Vasc Biol 2004, 24:288-293.

12. Awad O, Dedkov El, Jiao C, Bloomer S, Tomanek RJ, Schatteman GC: Differential healing activities of CD34+ and CD14+ endothelial cell progenitors. Arterioscler thromb vasc biol 2006, 26:758-764.

13. Friedrich EB, Walenta K, Scharlau J, Nickenig G, Werner N: CD34-/CD133 +/VEGFR-2+ endothelial progenitor cell subpopulation with potent vasoregenerative capacities. Circ res 2006, 98:e20-e25.

14. Urbich C, Dimmeler S: Risk factors for coronary artery disease, circulating endothelial progenitor cells, and the role of $\mathrm{HMG}-\mathrm{CoA}$ reductase inhibitors. Kidney int 2005, 67:1672-1676.

15. Dome B, Timar J, Dobos J, Meszaros L, Raso E, Paku S, Kenessey I, Ostoros G, Magyar M, Ladanyi A, Bogos K, Tovari J: Identification and clinical significance of circulating endothelial progenitor cells in human nonsmall cell lung cancer. Cancer res 2006, 66:7341-7347.

16. Marsboom G, Pokreisz P, Gheysens O, Vermeersch P, Gillijns H, Pellens M, Liu X, Collen D, Janssens S: Sustained endothelial progenitor cell dysfunction after chronic hypoxia-induced pulmonary hypertension. Stem Cells 2008, 26:1017-1026.

17. Furstenberger $G$, von Moos R, Lucas R, Thurlimann B, Senn HJ, Hamacher J, Boneberg EM: Circulating endothelial cells and angiogenic serum factors during neoadjuvant chemotherapy of primary breast cancer. Brit j cancer 2006, 94:524-531.

18. Khoo CP, Valorani MG, Brittan M, Alison MR, Warnes G, Johansson U, Hawa M, Pozzilli P: Characterization of endothelial progenitor cells in the NOD mouse as a source for cell therapies. Diab/metab res rev 2009, 25:89-93.

19. Hatzopoulos AK, Folkman J, Vasile E, Eiselen GK, Rosenberg RD: Isolation and characterization of endothelial progenitor cells from mouse embryos. Development 1998, 125:1457-1468.

20. Nolan DJ, Ciarrocchi A, Mellick AS, Jaggi JS, Bambino K, Gupta S, Heikamp E, McDevitt MR, Scheinberg DA, Benezra R, Mittal V: Bone marrow-derived endothelial progenitor cells are a major determinant of nascent tumor neovascularization. Genes dev 2007, 21:1546-1558.

21. Pitchford SC, Furze RC, Jones CP, Wengner AM, Rankin SM: Differentia mobilization of subsets of progenitor cells from the bone marrow. Cell stem cell 2009, 4:62-72.

22. Hackam DG, Redelmeier DA: Translation of research evidence from animals to humans. JAMA 2006, 296:1731-1732.

23. Clarkson TB, Prichard RW, Morgan TM, Petrick GS, Klein KP: Remodeling of coronary arteries in human and nonhuman primates. JAMA j Am Med Assoc 1994, 271:289-294.

24. Tohno Y, Tohno S, Laleva L, Ongkana N, Minami T, Satoh H, Oishi T, Hayashi M, Sinthubua A, Suwannahoy P, Mahakkanukrauh P: Age-related changes of elements in the coronary arteries of monkeys in comparison with those of humans. Biol trace elem res 2008, 125:141-153.

25. Stein A: Decreasing variability in your cell culture. Biotechniques 2007, 43:228-229

26. Asahara T, Murohara T, Sullivan A, Silver $M$, van der Zee $R, L i T$, Witzenbichler B, Schatteman G, Isner JM: Isolation of putative progenitor endothelial cells for angiogenesis. Science 1997, 275:964-967.

27. Fadini GP, Baesso I, Albiero M, Sartore S, Agostini C, Avogaro A: Technical notes on endothelial progenitor cells: ways to escape from the knowledge plateau. Atherosclerosis 2008, 197:496-503.

28. Takahashi T, Kalka C, Masuda H, Chen D, Silver M, Kearney M, Magner M, Isner JM, Asahara T: Ischemia- and cytokine-induced mobilization of bone marrow-derived endothelial progenitor cells for neovascularization. Nat Med 1999, 5:434-438.

29. Morineau N, Tang XW, Moreau P, Milpied N, Mahe B, Bataille R, Harousseau LL: Lack of benefit of CD34+ cell selected over non-selected peripheral blood stem cell transplantation in multiple myeloma: results of a single center study. Leukemia 2000, 14:1815-1820.

doi:10.1186/2050-490X-2-5

Cite this article as: Sun et al:: Isolation and characterization of endothelial progenitor cells from Rhesus monkeys. Regenerative Medicine Research 2014 2:5.

\section{Submit your next manuscript to BioMed Central and take full advantage of:}

- Convenient online submission

- Thorough peer review

- No space constraints or color figure charges

- Immediate publication on acceptance

- Inclusion in PubMed, CAS, Scopus and Google Scholar

- Research which is freely available for redistribution

Submit your manuscript at www.biomedcentral.com/submit
C Biomed Central 